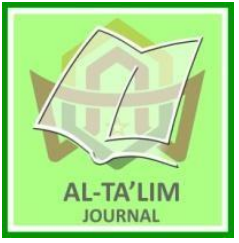

AL-TA'LIM JOURNAL, 28 (3), 2021, (283-294)

(Print ISSN 1410-7546 Online ISSN 2355-7893)

Available online at http://journal.tarbiyahiainib.ac.id/index.php/attalim

\title{
Students' Self-Adjustment with Boarding School Environment in MAN Insan Cendekia Lubuk Alung
}

Received: $23^{\text {th }}$ October 2020; Revised: $28^{\text {nd }}$ September 2021; Accepted: $30^{\text {th }}$ November 2021

Permalink/DOI: http://dx.doi.org/10.15548/it.v28i3.665

\section{Juliana Batubara *)}

Universitas Islam negeri Imam Bonjol

Padang, Indonesia.

E-mail: julianabatubara2011@gmail.com

\section{Darwin \\ Madrasah Aliyah Negeri Insan Cendekia Padang Pariaman, Indonesia. \\ E-mail: muhammadedwin2011@gmail.com}

\section{Ikhwanuddin \\ Universitas Islam Antarbangsa Malaysia. \\ E-mail: Ikhwan.iium2018@gmail.com}

\section{*) Corresponding Author}

\begin{abstract}
This research aims to describe and compare the selfadjustment of boarding school students with the school environment in terms of gender (comparative descriptive study of students at MAN Insan Cendekia Lubuk Alung, West Sumatra). This type of research is descriptive-comparative with a questionnaire instrument. The population of all students of class $\mathrm{X}$, sampling with purposive random sampling technique in order to obtain a sample of 82 students. Data were analyzed by descriptive statistical analysis, and to test the differences used $t$ test. The results showed that in general the self-adjustment of boarding school students with the school environment of MAN Insan Cendekia Lubuk Alung, West Sumatra was classified high and there was a significance difference from the self-adjustment of male and female students. Therefore, school counselors can provide various types of counseling and guidance services to students of MAN Insan Cendekia Lubuk Alung, West Sumatra so that they are able to overcome difficulties in their selfadjustment by fostering self-confidence and training students how to adapt to the new environment and atmosphere in accordance with the rules.
\end{abstract}

\section{*) Corresponding Author}

Keywords: Boarding school; self-adjustment; school environment.

How to Cite: Batubara, J., Darwin, D., \& Ikhwanuddin, I. (2021). Students' Self-Adjustment with Boarding School Environment in MAN Insan Cendekia Lubuk Alung. Al-Ta lim Journal, 28(3), 283-294. doi:https://doi.org/10.15548/jt.v28i3.665

\section{INTRODUCTION}

Every human being who is born into the world has different abilities, both talents, interests, creativity, and other abilities so that it requires development to become a real man(Nussbaum, 2011; Trevarthen, 2011). The effort of human development is to develop all the potential that exists in an individual human being with all of his dimensions as a result he becomes a man who is balanced between his individual and social life, his physical and spiritual life as well as in the world and the hereafter(Orel, 2019; Stolarski et al., 2016).

To reach all these, education is needed because as we know that education is a conscious human effort in molding students into our human beings of knowledge and values. The educational process is not only used as a process of knowledge transformation but the inculcation of values is also carried out in students(Irby, 2014; Paralič et al., 2013; Wieser, 2016). This is so that 
students can lead a good life and be accepted by the wider community after graduating from schools.Education that changes students' perspectives and viewpoints to create a sustainable future (Mitchell \& Weber, 2013).

The objective of national education is "the development of the potential of students to become human beings who believe and have faith in God Almighty, having noble character, healthy, knowledgeable, capable, creative, independent and become democratic and responsible citizens" (SISDIKNAS Law, 2003). This educational goal can be achieved through formal, informal and non-formal education. These three educational paths complement and enrich each other. One of the formal educations in Indonesia is boarding school. According to Halik (2016), a boarding school is an educational institution where students not only learn, but they stay and live together inside the school. The boarding schools combine student residences in the institutions that are far away from their homes and families with being taught religion and learning several subjects (Alwi, 2013; Julhadi, 2019; Rahman, 2018). Therefore, students need to adapt to a new environment starting from new friends, new teachers and even the rules they have just obtained regarding the environment and extracurricular activities to support their academic achievement (GómezOrtiz et al., 2017; Mander \& Lester, 2017; Ottu et al., 2020; Pfeiffer et al., 2016). Proper adaptation to the social environment will affect achievement motivation (Wang \& Eccles, 2013). Achievement motivation during the study period is considered as one of the important motives in guiding students' behavior towards accepting challenges in situations that require excellence, and for making serious efforts in achieving success(Awan et al., 2011; Guo et al., 2015; Singh, 2011).

Self-adjustment is a process that includes mental and behavioral responses which are individual efforts to overcome and control their inner needs, tensions, frustrations, and conflicts so that there is harmony between the demands from within with the demands or expectations of the environmental residences (Maranata et al.,
2019; Noviandari \& Mursidi, 2019; Rafikayati et al., 2018; Rusnila et al., 2021; R. O. Sari, 2020). Self-adjustment demands the ability of students to live and associate naturally with new environments so that students feel satisfied with themselves and their surroundings. Self-adjustment is a process of how individuals achieve selfbalance to face their needs in accordance with environmental demands (da Costa et al., 2018; Hidayah, 2021; Li et al., 2017). In addition, self-adjustment can also be interpreted as a natural and dynamic process as well as a form of interaction based on acceptance and self-approach that aims to change individual behavior so that relationships are more appropriate to the environmental conditions (Japar, 2014; Nanson \& Huang, 2017; Sari \& Arsyad, 2021).

Several researches regarding selfadjustment of new students who live in the Islamic boarding schools can be concluded that there are changes experienced by students before living and after living in the boarding school, namely: 1) Different rules at home and at the boarding school. Students at home are not bound by rules that must be obeyed and they can feel free to do whatever they want. The busy schedule every day at the schools is different while at home. Every day in the school students must follow a routine schedule from getting up early until late night to sleep again, while at home the existing schedule is not as tight as in the schools and cannot be free as desired (Finn, 2012; Williams, 2011). 2) Independent. Students do not always do all their own duties at home. For example, cleaning the room, washing clothes, ironing, washing dishes after eating where are not always done by students themselves because there may be helpers but when in the boarding school all of these must be done by students(Beames et al., 2020; F. W. Santoso \& Fahyuni, 2022; Stern, 2021).Therefore, students are required to be independent. Changes that occur in the boarding school environment can cause stress at the beginning of school.

Research by Yuniar et al. (2005) showed that every year between $5-10 \%$ of 
new students at the Islamic Modern Islamic Boarding School (PPMI) Assalam Surakarta faced problems in the self-adjustment process, such as not being able to attend lessons, unable to live in dormitories because they cannot live separated from parents, so they can violate the rules of the school and so on. Conditions in the boarding school with different rules and conditions than at home can be a source of stress (stressor) that can cause stress. The bad result of stress is fatigue which can be decreased productivity in studying and personal activities(Khaer et al., 2021; Mahfar et al., 2019; Mukhlis et al., 2020; Muslimah et al., 2019; Wahab et al., 2013).

Madrasah Aliyah Negeri Insan Cendekia (MAN IC) West Sumatera is one of the educational institutions that uses the boarding school system. Students must live in a hostel that has been provided with different rules and conditions from schools in general. Students must face changes that occur in themselves, both from the social side, the learning system and the subjects that must be followed and the rules in the school hostel that require independence and away from parents. Based on the results of interviews with MAN Insan Cendekia West Sumatera's teachers in March 2018, it was revealed that the student activities at the boarding school were quite full, starting from 04.00 am to 22.00 WIB. All activities have a governing system so that no time is wasted. However, there are still many students who complain that the nighttime rest time is too fast, so they feel that they lack time to do assignments. To get maximum learning outcomes, students need a good self-adjustment (Martin et al., 2014).

If a student is successful in the selfadjustment process, then that student feels safe, happy, has a positive attitude and outlook. On the other hand, students who experience poor self-adjustment, have a psychological life characterized by emotional shock or anxiety that accompanies guilt, anxiety, feeling dissatisfied with what has been obtained, and complaints about what they have experienced, leading to wrong behavior patterns or violates school discipline. This is a self-adjusting which is marked by attitudes and behavior that are awry, undirected, emotional, unrealistic, blind, and so on (Mander \& Lester, 2019; Wahyuni \& Barus, 2020).

\section{METHOD}

This research uses a comparative descriptive quantitative approach. The study will describe and compare students' selfadjustment in terms of gender, namely male and female. The population in this study were all students of MAN Insan Cendekia Lubuk Alung West Sumatra. The number of samples was 82 people who were selected by purposive random sampling technique. The instrument used was a questionnaire that revealed students' self-adjustment.

Data obtained from respondents were processed and categorized into 5 categories, namely very high, high, medium, low, and very low. Data were analyzed using descriptive statistics and for different tests used the $t$-test(Winarsunu, 2017). A database was set up and a coding for the data entry of the completed questionnaires was organised. The data from the questionnaires were entered into MS Excel software and the quantitative data was analyzed using IBM SPSS (version 20) with emphasis on frequency

counts, percentage distribution, graphical display and measures of central tendency.

\section{RESULTS AND DISCUSSIONS}

Description of Self-adjustment of Boarding School Students with the School Environment of MAN Insan Cendekia Lubuk Alung, West Sumatera. The data obtained are arranged in a table that describes the respondents' data in predetermined categories and is then described in the percentage value (\%) obtained. The description of the selfadjustment of the MAN Insan Cendekia boarding school students with the school environment in terms of gender can be seen in table 1 below. 
Table 1. Distribution Score of Self-adjustment Regarding Gender

\begin{tabular}{ccccc}
\hline Gender & N & Mean & Sd & Level \\
\hline Female & 41 & 184,12 & 19,46 & High \\
Male & 41 & 177,81 & 13,18 & High
\end{tabular}

Based on table 1 it can be seen that the self-adjustment of female students of boarding school MAN Insan Cendekia Lubuk Alung West Sumatera with the school environment is classified as high. This can be seen from the acquisition of a mean of 184.12 (with an ideal score of 245) and a standard deviation of 19.46. Meanwhile, the selfadjustment of male students of boarding school MAN Insan Cendekia Lubuk Alung West Sumatera with the school environment is also classified as high. This can be seen from the acquisition of a mean of 177.81 (with an ideal score of 245) and a standard deviation of 13.18 .

TheDifferences between the SelfAdjustment of both Male and Female Students with the School Environment in MANInsan Cendekia Lubuk AlungWest Sumatera

The differences of students' selfadjustment of both male and female students with the school environment in MAN Insan Cendekia Lubuk Alung, West Sumatera can be seen as following table II.

Table 2. The Differences of Students' Self-adjustment Regarding Gender

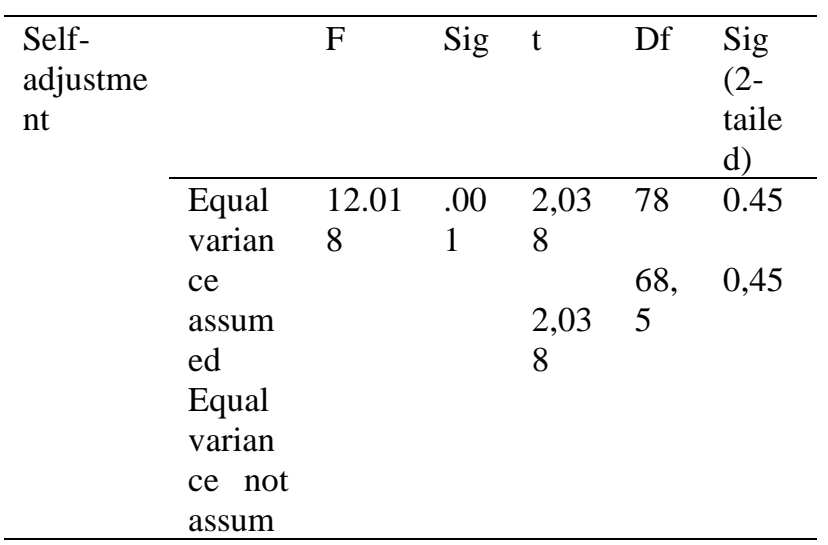

ed

The $F$ obtained from the research data is 12.018 with a significance of 0.001 (less than 0.05), then the $t$ used is Equal variance not assumed of 2.038 with a probability of 0.045 (small than 0.05). This means that there are differences between the two variants. In more detail, the results of data analysis by looking at the $t$, the $\mathrm{t}$ is 2.038 , degrees of freedom (df) 68.55 with a significance of 0.045 (smaller than 0.05). Because the $t$ obtained is 2.038 while the $t$ table value is 1.990 , the result of $t$ is greater than the $t$ table at a significant level. Thus, there is a significant difference. Therefore, it can be concluded that there is a significant difference between the self-adjustment of male and female students of MAN Insan Cendekia Lubuk Alung, West Sumatera.

Based on the results of the research that has been done, it can be seen that the selfadjustment of the students of MAN Insan Cendekia Lubuk Alung, West Sumatera in terms of gender can be categorized as high. To live and get along naturally in the new school environment, students will try to adjust to the environment well. The relationship between individuals and the environment is a basic relationship that is important for adolescent development (Lerner, 2017; Lerner et al., 2011, 2015; Ruch et al., 2014).

Peer relationships for teenagers are very important. One of the reasons is that adolescents have a strong need to be preferred and accepted as peers or groups (Santrock, 2008; Hurlock, 1997). They will feel happy when accepted then will feel very depressed 
and anxious when being expelled by the group. In addition, establishing a harmonious relationship with peers will help adolescents understand themselves and be able to live in a boarding school (Pfeiffer et al., 2016). This means that the better the relationship with peers, the self-adjustment process will be better. This will greatly affect the academic achievement that will be obtained by students (Bailey \& Phillips, 2016; Rienties et al., 2012).

Every individual who are welladjusted are able to: (1) perceive reality appropriately, (2) make use of experiences and make further plans, (3) gain job satisfaction, (4) have intimate social relationships, (5) feel and express life emotion, (6) able to see himself objectively (Watson \& Tharp, 2013). They also agree that self-adjustment is essentially as a social concept which related to the individual environment.The self-adjustment problems faced by students are thought to be influenced by several factors, both internal and external. The factors that influence students' selfadjustment are "1) Physical conditions and determinants, including heredity, physical construction, the nervous, glandular, and muscular system, health, illness, and fortune, 2) Development and maturation, particularly intellectual, social, moral, and emotional maturation, 3) Psychological determinants, including experiences, learning, conditioning, self-determination, frustration, and conflict, 4) Environmental conditions, particularly the home, family, and school, 5) Cultural determinants, including religion (Haktanir et al., 2021; Jones et al., 2012; Rodrigues et al., 2019; Wouters et al., 2011).

One of the factors that influences individual self-adjustment is the level of religiosity and culture. National culture influences individual perceptions, behaviors and beliefs (Cantwell \& Verbeke, 2017; Hoff \& Bashir, 2015; Schwartz, 2013; Swidler, 2013). Culture in a society is a factor that shapes the character and behavior of individuals to adapt well. Cultural assumptions and values describe the nature of the relationship between humans and the environment and between humans and themselves (Smircich, 2017). The social and cultural environment that underlies different individuals causes differences in the selfadjustment process.

School is a place where formal education takes place which aims to develop students' abilities and potential, especially the development of intelligence and personality. Schools must be able to foster good selfadjustment and be constructive in nature so that discipline can be realized with school regulations, recognition of teacher authority, interest in subjects in schools and sufficient situations and facilities as a result schoolgoalscan be achieved (Hanurawan, 2012). "The school is universally recognized as a powerful medium for influencing the intellectual, social, and moral lives of students. It is the primary agent of education". Schools not only provide education for individuals in intellectual terms, but also in social and moral aspects in daily life, education from schools is also needed. Schools also influence the formation of interests, beliefs, attitudes and values that are the basis for good self-adjustment(Hamid, 2017; Putri et al., 2015; M. B. Santoso, 2016).

Students' self-adjustment in the school environment consists of "adjusting to peers, with teachers, adjusting to parent-teacherstudent relationships, adjusting to academic demands and with the physical and social environment of the school" (Al-Mighwar, 2011; Wang \& Eccles, 2012; Willis, 2012). This will provide different opportunities for student growth and development.

The self-adjustment of male and female students at MAN Insan Cendekia Lubuk Alung, West Sumatera is different. When we see from the average of all the existing sub-variables, it describesthatfemale studenthave more abilities and skills in adapting to the environment compared to male students (Surna \& Pandeirot, 2014). This is because female students are more competent in communicating and have a close character with peers.

Students of MAN Insan Cendekia Lubuk Alung, West Sumatera are generally in 
the age range of 15-16 years. When we see from a psychological aspect, this age is a period of adolescence. Entering this period, individuals face many situations and new developmental tasks, namely between independence and dependence on parents. In this change, individuals are required to be able to adjust to both male and female. It is predicted that gender difference will also influence the success of students' selfadjustment. This difference in self-adjustment is due to the fact that female have feelings that are more sensitive compared to men so that they are easier to appreciate the feelings of others and tend to have closer social relationships than male. This differences in self-adjustment occurs because of differences in the treatment of male and female in society. Males are more active, freer and tend to be looser in opposing the rules and norms of society while females are more accustomed to following norms, so it will be easier to adjust themselves in the social environment.

Gender and self-worth that an individual has can affect his self-adjustment to others. The influence of gender on selfdisclosure stems from differences in the treatment of parents to children due to differences in gender. Differences in biological categories between male and female also produce cultural practices in the form of parenting patterns, roles, gender differences, and sex role ideologies that lead to acts of separation between male and female.

The different parenting patterns, for example, are in the form of differences in the way adults talk to boys and girls. Parents, siblings, peers, teachers and other adults talk to boys and girls in different ways because they have different expectations and role criteria for both. The roles imposed on male and female can ultimately be a gender differences, namely a belief about a set of meanings associated with both male and female. This meaning relates to appearance, appropriate body shape, ways of behaving, ways of earning a living, and appropriate ways of speaking. The different ways of communicating between male and female are also different. Male have more control over verbal skills, such as telling stories, joking and lecturing on information, while female tend with private conversations. Gender differences for male and female that have been formed and developed in society become a reference for individuals to behave. Gender differences expect each individual to be able to accept the fact that they must adjust to the agreed differences in gender roles if they want to get good social acceptance (Hurlock, 1997).

One of the factors that influence selfadjustment is emotional development. A person's emotional development affects selfadjustment, both in male and in female. Female tend to be better at processing their emotions than male. Female also look more mature than male). One manifestation of this factor is that female maintain a relationship with conversation and verbal skills. On the other hand, male socialize is more active by playing with sports, computer games and playing on the field and prefer to make noise in class. This pattern of behavior is then affirmed by the teacher in the class. Moreover, male noise by paying more attention to them and the behavior of men who prefer to make noise is one aspect that teachers pay attention to and this behavior causes teachers to have lower expectations than female in terms of learning.

\section{CONCLUSIONS AND RECOMMENDATION}

Based on the results of research on the self-adjustment of the boarding school students of MAN Insan Cendekia Lubuk Alung West Sumatera with the school environment in terms of gender, the following conclusions can be drawn: (1) the selfadjustment of boarding school students of MAN Insan Cendekia Lubuk Alung West Sumatera with a relatively high school environment. (2) There is a difference between the self-adjustment of male and female students with the school environment in MAN Insan Cendekia Lubuk Alung, West Sumatra. Female students have the ability and skills to interact socially with the environment higher than male students. 
Therefore, recommendations are put forward in the form of suggestions to (1) students of MAN Insan Cendekia Lubuk Alung West Sumatera in order to be able to maintain and improve their ability to adapt themselves to the new environment, both in adjusting to the department occupied, in following the learning system well, in fostering good interpersonal relationships, in using and utilizing learning facilities and infrastructure, participating in extra activities and adjusting to comply with applicable rules in the learning process. (2) the supervisor can provide various types of counseling services and guidance to students of MAN Insan Cendekia Lubuk Alung, West Sumatera so that they are able to overcome their difficulties by fostering self-confidence and training students how to adapt to new environments and new situations both from the rules at school and the rules in the dormitory. (3) further research should be re conducted and follow up this research result with wider population so that the result of the study can be combined and become as a reference for whole academic needs.

\section{REFERENCES}

Al-Mighwar, M. (2011). Psikologi remaja cetakan II. Bandung: CV. Pustaka

Setia.Alwi, B. M. (2013). Pondok pesantren: Ciri khas, perkembangan, dan Sistem Pendidikannya. Lentera Pendidikan: Jurnal Ilmu Tarbiyah Dan Keguruan, 16(2), 205-219. https://doi.org/10.24252/lp.2013v16n2 a8

Awan, R.-U.-N., Noureen, G., \& Naz, A. (2011). A Study of Relationship between Achievement Motivation, Self Concept and Achievement in English and Mathematics at Secondary Level. International Education Studies, 4(3), 72-79.

Bailey, T. H., \& Phillips, L. J. (2016). The influence of motivation and adaptation on students' subjective well-being, meaning in life and academic performance. Higher Education Research \& Development, 35(2), 201- 216.https://doi.org/10.1080/07294360. 2015.1087474

Beames, S., Mackie, C., \& Scrutton, R. (2020). Alumni perspectives on a boarding school outdoor education programme. Journal of Adventure Education and Outdoor Learning, 20(2),

123-137.

https://doi.org/10.1080/14729679.201 8.1557059

Cantwell, J., \& Verbeke, A. (2017). The JIBS 2016 Decade Award: A quarter century of Culture's Consequences: a review of empirical research incorporating Hofstede's cultural values framework. In Journal of International Business Studies (Vol. 48, Issue 1, pp. 10-11). Springer.

da Costa, A., Hanurawan, F., Atmoko, A., \& Hitipeuw, I. (2018). The impact of self-adjustment on academic achievement of the students. ISLLAC: Journal of Intensive Studies on Language, Literature, Art, and Culture, 2(1), 1-6. http://dx.doi.org/10.17977/um006v2i1 2018p001

Finn, P. J. (2012). Preparing for power in elite boarding schools and in working-class schools. Theory Into Practice, 51(1), 57-63.

https://doi.org/10.1080/00405841.201 2.636339

Gómez-Ortiz, O., Romera-Felix, E.-M., \& Ortega-Ruiz, R. (2017). Multidimensionality of social competence: Measurement of the construct and its relationship with bullying roles. Revista de Psicodidáctica (English Ed.), 22(1), 37-44.

https://doi.org/10.1387/RevPsicodidac t. 15702

Guo, J., Parker, P. D., Marsh, H. W., \& Morin, A. J. (2015). Achievement, motivation, and educational choices: A longitudinal study of expectancy and value using a multiplicative 
perspective.

Psychology, 51(8), 1163.

Developmental

Haktanir, A., Watson, J. C., Ermis-Demirtas, H., Karaman, M. A., Freeman, P. D., Kumaran, A., \& Streeter, A. (2021). Resilience, academic self-concept, and college adjustment among first-year students. Journal of College Student Retention: Research, Theory \& Practice, 23(1), 161-178. https://doi.org/10.1177/152102511881 0666

Halik, A. (2016). Paradigm of Islamic Education in the Future: The Integration of Islamic Boarding School and Favorite School. Information Management and Business Review, 8(4), 24-32. https://doi.org/10.22610/imbr.v8i4.13 90

Hamid, A. (2017). Agama dan kesehatan mental dalam perspektif psikologi agama. Healthy Tadulako Journal (Jurnal Kesehatan Tadulako), 3(1), 114.

https://doi.org/10.22610/imbr.v8i4.13 90

Hanurawan, F. (2012). Strategi pengembangan kesehatan mental di lingkungan sekolah. Jurnal Bimbingan Dan Konseling, 14(2), 93.

Hidayah, R. (2021). Students' SelfAdjustment, Self-Control, and Morality. Journal of Social Studies Education Research, 12(1), 174-193. https://www.learntechlib.org/p/219413 /.

Hoff, K. A., \& Bashir, M. (2015). Trust in automation: Integrating empirical evidence on factors that influence trust. Human Factors, 57(3), 407-434. https://doi.org/10.1177.001872081454 7570

Irby, D. M. (2014). Excellence in clinical teaching: Knowledge transformation and development required. Medical
Education, 48(8), 776-784. у 2014. https://doi.org/10.1111/medu.12507

Japar, M. (2014). Religiousity, Spirituality and Adolescents' Self-Adjustment. International Education Studies, 7(10), 66-73. http://dx.doi.org/10.5539/ies.v7n10p6 6

Jones, M. H., Audley-Piotrowski, S. R., \& Kiefer, S. M. (2012). Relationships among adolescents' perceptions of friends' behaviors, academic selfconcept, and math performance. Journal of Educational Psychology, 104(1), 19.

Julhadi, J. (2019). Pondok Pesantren: Ciri Khas, Perkembangan, dan Sistem Pendidikannya. Mau'izhah, 9(2).

Khaer, M., Mansyur, A. Y., Ridfah, A., \& Ridha, A. A. (2021). The Effectiveness Of Writing The Letter Of Gratitude Technique In Reducing The Stress Level Of Islamic Boarding School Student. Psikis: Jurnal Psikologi Islami, 7(1), 7985. https://doi.org/10.19109/psikis.v7i 1.4612

Lerner, R. M. (2017). Commentary: Studying and testing the positive youth development model: A tale of two approaches. Child Development, 88(4), $\quad 1183-1185 . \quad 7$ https://doi.org/10.1111/cdev.12875

Lerner, R. M., Lerner, J. V., Bowers, E. P., \& Geldhof, G. J. (2015). Positive youth development and relationaldevelopmental-systems.

Lerner, R. M., Lerner, J. V., Lewin-Bizan, S., Bowers, E. P., Boyd, M. J., Mueller, M. K., Schmid, K. L., \& Napolitano, C. M. (2011). Positive youth development: Processes, programs, and problematics. Journal of Youth Development, 6(3), 38-62. https://doi.org/10.5195/jyd.2011.174

Li, Y., Wen, Z., Cao, Y., Tan, Y., Sidorov, D., \& Panasetsky, D. (2017). A 
combined forecasting approach with model self-adjustment for renewable generations and energy loads in smart community. Energy, 129, 216-227. https://doi.org/10.1016/j.energy.2017. 04.032

Mahfar, M., Noah, S. M., \& Senin, A. A. (2019). Development of rational emotive education module for stress intervention of Malaysian boarding school students. Sage Open, 9(2), 2158244019850246.

https://doi.org/10.1177/215824401985 0246

Mander, D. J., \& Lester, L. (2017). A longitudinal study into indicators of mental health, strengths and difficulties reported by boarding students as they transition from primary school to secondary boarding schools in Perth, Western Australia. Journal of Psychologists and Counsellors in Schools, 27(2), 139152.

https://doi.org/10.1017/jgc.2017.1

Mander, D. J., \& Lester, L. (2019). The selfreported perceptions, readiness and psychological wellbeing of primary school students prior to transitioning to a secondary boarding school. Children Australia, 44(3), 136-145. https://doi.org/10.1017/cha.2019.20

Maranata, P., Wibowo, M. E., \& Sugiharto, D. Y. P. (2019). The Effectiveness of Rational Emotive Behavior Therapy Group Counseling to Reduce Loneliness through Increasing SelfAdjustment for New College Students. Jurnal Bimbingan Konseling, 8(2), 182-187. https://doi.org/10.15294/jubk.v8i2.284 91

Martin, A. J., Papworth, B., Ginns, P., \& Liem, G. A. D. (2014). Boarding school, academic motivation and engagement, and psychological wellbeing: A large-scale investigation. American Educational Research Journal, 51(5), 1007-1049. https://doi.org/10.3102/000283121453 2164

Mitchell, C., \& Weber, S. (2013). Just who do we think we are... And how do we know this?: Re-visioning pedagogical spaces for studying our teaching selves. In Just Who Do We Think We Are? (pp. 17-25). Routledge.

Mukhlis, H., Kristianingsih, A., Fitrianti, F., Pribadi, T., Kumalasari, D., Febriyanti, H., \& Maseleno, A. (2020). The effect of expressive writing technique to stress level decrease of new student at Al-Falah Putri Islamic Boarding School, Margodadi, Tanggamus. Annals of Tropical Medicine and Public Health, 23, 192-200.

http://doi.org/10.36295/asro.2020.236 24

Muslimah, M., Hamdanah, H., Syakhrani, A. W., \& Arliansyah, A. (2019). Stress and Resilience in Learning and Life in Islamic Boarding School: Solutions for Soft Approaches to Learning in Modern Times. Nazhruna: Jurnal Pendidikan Islam, 2(3), 421-433.

Nanson, G. C., \& Huang, H. Q. (2017). Selfadjustment in rivers: Evidence for least action as the primary control of alluvial-channel form and process. Earth Surface Processes and Landforms, 42(4), 575-594. 016. https://doi.org/10.1002/esp.3999

Noviandari, H., \& Mursidi, A. (2019). Relationship of Self Concept, Problem Solving and Self Adjustment in Youth. International Journal for Educational and Vocational Studies, 1(6), 651-657. https://doi.org/10.29103/ijevs.v1i6.15 99

Nussbaum, M. C. (2011). Capabilities, entitlements, rights: Supplementation and critique. Journal of Human Development and Capabilities, 12(1), 23-37. 
https://doi.org/10.1080/19452829.201 1.541731

Orel, M. (2019). Coworking environments and digital nomadism: Balancing work and leisure whilst on the move. World Leisure Journal, 61(3), 215-227. https://doi.org/10.1080/16078055.201 9.1639275

Ottu, I. F., Umoren, A. M., Umoh, G. R., \& Sunday, J. R. (2020). Self-Monitoring, Peer-bullying and Parenting Style in Prosocial Behaviours of Boarding School Students. Nigerian Journal of Social Psychology, 3(1).

Paralič, J., Babič, F., \& Paralič, M. (2013). Process-driven approaches to knowledge transformation. Acta Polytechnica Hungarica, 10(5), 125143.

https://doi.org/10.1177/082957351663 0303

Pfeiffer, J. P., Pinquart, M., \& Krick, K. (2016). Social relationships, prosocial behaviour, and perceived social support in students from boarding schools. Canadian Journal of School Psychology, 31(4), 279-289. https://doi.org/10.1177/082957351663 0303

Putri, A. W., Wibhawa, B., \& Gutama, A. S. (2015). Kesehatan mental masyarakat Indonesia (pengetahuan, dan keterbukaan masyarakat terhadap gangguan kesehatan mental). Prosiding Penelitian Dan Pengabdian Kepada Masyarakat, 2(2). https://doi.org/10.24198/jppm.v2i2.13 535

Rafikayati, A., Badian, L. I., \& Soedarmadji, B. (2018). The Role of Counseling Guidance Teacher for Helping Self Adjustment of Special Needs Children in Inclusion School. Advances in Social Science, Education and Humanities Research, 272.

Rahman, K. (2018). Perkembangan Lembaga Pendidikan Islam di Indonesia.

\section{Tarbiyatuna: Kajian Pendidikan} Islam, 2(1), 1-14.

Rienties, B., Beausaert, S., Grohnert, T., Niemantsverdriet, S., \& Kommers, P. (2012). Understanding academic performance of international students: The role of ethnicity, academic and social integration. Higher Education, 63(6), 685-700.

Rodrigues, H., Almeida, F., Figueiredo, V., \& Lopes, S. L. (2019). Tracking elearning through published papers: A systematic review. Computers \& Education, 136, 87-98. https://doi.org/10.1016/j.compedu.201 9.03.007

Ruch, W., Weber, M., \& Park, N. (2014). Character strengths in children and adolescents. European Journal of Psychological Assessment. 014. https://doi.org/10.1027/10155759/a00 0169

Rusnila, R., Daharnis, D., \& Syukur, Y. (2021). Analysis of student adjustment in dormitory based on type of school, cultural background and grade level. International Journal of Research in Counseling and Education, 5(1), 6271. https://doi.org/10.24036/00417za0 002

Santoso, F. W., \& Fahyuni, E. F. (2022). Boarding School Program Management and School Culture on Independent Learning of Students at Junior Boarding School. Academia Open, 6, 10-21070.

Santoso, M. B. (2016). Kesehatan mental dalam perspektif pekerjaan sosial. Share: Social Work Journal, 6(1). https://doi.org/10.24198/share.v6i1.13 160

Sari, N. P., \& Arsyad, M. (2021). Environment and Differences of Self Adjustment Ability Between Students of Natural Sciences Programs and Students of Social Sciences Programs. The 2nd International Conference on 
Social Sciences Education (ICSSE 2020), 315-321.

Sari, R. O. (2020). Self-adjustment of candidate counsellor student who is forced in taking a guidance and counselling department. Journal of Physics: Conference Series, 1567(4), 042022. https://doi.org 10.1088/1742$6596 / 1567 / 4 / 042022$

Schwartz, S. H. (2013). Culture matters: National value cultures, sources, and consequences. In Understanding culture (pp. 137-160). Psychology Press.

Singh, K. (2011). Study of achievement motivation in relation to academic achievement of students. International Journal of Educational Planning \& Administration, 1(2), 161-171.

Smircich, L. (2017). Concepts of culture and organizational analysis. The Anthropology of Organisations, 255274.

Stern, T. (2021). Retention Efforts at an Independent Boarding School $[\mathrm{PhD}$ Thesis].

Stolarski, M., Vowinckel, J., Jankowski, K. S., \& Zajenkowski, M. (2016). Mind the balance, be contented: Balanced time perspective mediates the relationship between mindfulness and life satisfaction. Personality and Individual Differences, 93, 27-31. https://doi.org/10.1016/j.paid.2015.09. 039

Surna, I. N., \& Pandeirot, O. D. (2014). Psikologi Pendidikan 1. Jakarta: Erlangga.

Swidler, A. (2013). Talk of love: How culture matters. University of Chicago Press.

Trevarthen, C. (2011). What is it like to be a person who knows nothing? Defining the active intersubjective mind of a newborn human being. Infant and Child Development, 20(1), 119-135.
Wahab, S., Rahman, F. N. A., Wan Hasan, W. M. H., Zamani, I. Z., Arbaiei, N. C., Khor, S. L., \& Nawi, A. M. (2013). Stressors in secondary boarding school students: Association with stress, anxiety and depressive symptoms. Asia-Pacific Psychiatry, 5, 82-89.

https://doi.org/10.1111/appy.12067

Wahyuni, N. S., \& Barus, N. (2020). The Adaptation Differences in Terms of Gender on Students in Ulumul Qur'an Stabat Islamic Boarding School. Budapest International Research and Critics Institute (BIRCI-Journal): Humanities and Social Sciences, 3(1), 417-427. https://doi.org/10.33258/birci.v3i1.7

Wang, M.-T., \& Eccles, J. S. (2012). Adolescent behavioral, emotional, and cognitive engagement trajectories in school and their differential relations to educational success. Journal of Research on Adolescence, 22(1), 3139.https://doi.org/10.1111/j.15327795. 2011.00753.X

Wang, M.-T., \& Eccles, J. S. (2013). School context, achievement motivation, and academic engagement: A longitudinal study of school engagement using a multidimensional perspective. Learning and Instruction, 28, 12-23. https://doi.org/10.1016/j.learninstruc. 2 013.04 .002

Watson, D. L., \& Tharp, R. G. (2013). Selfdirected behavior: Self-modification for personal adjustment. Cengage Learning.

Wieser, C. (2016). Teaching and personal educational knowledge-conceptual considerations for research on knowledge transformation. European Journal of Teacher Education, 39(5), 588-601. https://doi.org/10.1080/02619768.201 6.1253673 
Williams, R. (2011). The socialization of the power elite in an American boarding school [PhD Thesis].

Willis, S. S. (2012). Psikologi pendidikan. Bandung: Alfabeta, 67, 71-73.

Winarsunu, T. (2017). Statistik dalam penelitian psikologi dan pendidikan (Vol. 1). UMMPress.

Wouters, S., Germeijs, V., Colpin, H., \& Verschueren, K. (2011). Academic self-concept in high school: Predictors and effects on adjustment in higher education. Scandinavian Journal of Psychology, 52(6), 586-594. https://doi.org/10.1111/j.14679450.2 011.00905.x

Yuniar, M., Abidin, Z., \& Astuti, T. P. (2005). Penyesuaian Diri Santri Putri TerhadapKehidupan Pesantren: Studi Kualitatif pada Madrasah Takhasusiah Pondok Pesantren Modern Islam Assalam Surakarta. Jurnal Psikologi Undip, 2(1), 10-17. 